\title{
Wind Pressure Coefficients on Greenhouse Structures
}

\author{
Chrysanthos Maraveas (D) \\ Department of Civil Engineering, University of Patras, 26500 Patra, Greece; c.maraveas@maraveas.gr
}

Received: 18 March 2020; Accepted: 30 April 2020; Published: 1 May 2020

\begin{abstract}
Commercial production greenhouses are widely used to produce plants and crops. From the structural engineering viewpoint, among the loads that act on greenhouses, wind and snow loads are the major ones. This paper focuses on the former, particularly on wind pressure coefficients. Design and construction of greenhouses should consider wind loads in order to ensure seamless operation, overall stability, durability, and safety, even though human occupancy is limited. Classification and design of greenhouses is typically based on European standards, which cover a variety of geometries and conditions. Some recent research studies suggest, however, that greenhouse design standards should be revised to ensure structural safety of greenhouses subject to strong wind loads. Triggered by this recent outcomes, this paper reviews existing literature on the topic: (a) briefly presenting the state of the art methods for determining wind pressures on greenhouses; (b) comparing the EN 13031-1 pressure coefficients with those stemming from recent experimental studies on single-span pitched and arched roof greenhouses in South Korea; and (c) summarizing most recent comparative results for multi-span greenhouses. It concludes that these recent research studies are not enough to justify revision of EN 13031-1, and more measurement data and experimental or numerical studies are necessary to justify such a conclusion.
\end{abstract}

Keywords: commercial greenhouses; wind loads; wind pressure coefficients; European standards; wind tunnels

\section{Introduction}

Greenhouses are light structures in which plants requiring regulated climatic conditions are grown. Greenhouses for production of plants and crops, where human presence is limited to authorized personnel, are called commercial production greenhouses. These structures vary in type, size, and material and are designed to allow for higher efficiency and better control of plants and crops cultivation.

Europe and North America constitute the fastest growing markets for commercial greenhouses [1]. In Europe, the evolution of controlled environment agriculture took place due to the favorable climate conditions for the adoption of greenhouse automation technologies, which were further encouraged and financed by the corresponding authorities. Many European companies have invested extensively in research areas related to greenhouse automation, including climate control, lighting, and material handling. These developments in controlled environment agriculture have made Europe a major market for commercial greenhouses, with the Netherlands having some of the largest greenhouses in the world (Figure 1) [2]. 


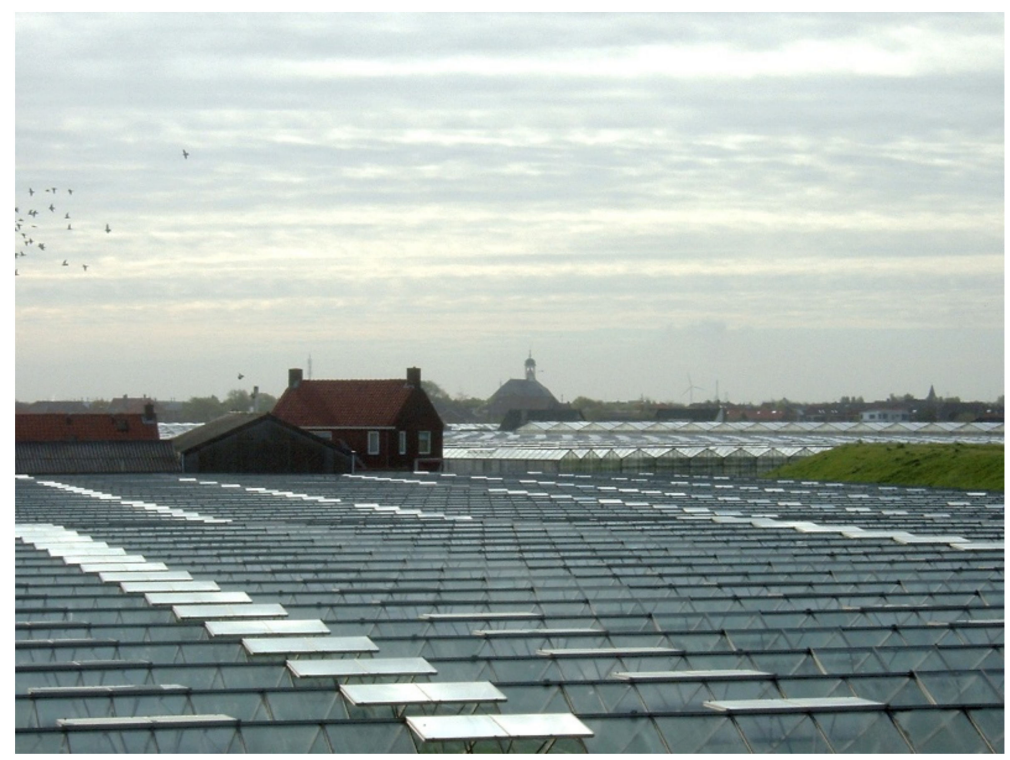

Figure 1. A sea of greenhouses in the Westland region of the Netherlands [2].

From a structural engineering viewpoint, greenhouses constitute light structures, whose frames are typically made of steel or aluminum. The cladding, that is the outer skin of roof and wall attached to the structural framework of the greenhouse, is typically made of glass or plastic panels. The loads acting on greenhouses can be categorized as follows [3]:

1. Permanent loads: self-weight, permanently present installation loads

2. Variable loads: wind loads, snow loads, crop loads, thermal loads, concentrated vertical loads, and incidentally present installation loads

3. Accidental loads: impact loads and exceptional snow loads

Among all these loads, wind and snow loads are the major ones. This paper focuses on wind pressure coefficients and presents a review of the Eurocode standards as well as of the recent literature on the topic. For detailed studies on wind loads the reader is referred to other extensive works, such as those of Cook [4,5]. The paper is structured as follows. Section 2 summarizes the wind loading specifications of EN 13031-1 [3] and EN 1991-1-4 [6] standards. Section 3 presents the computational methods for determining wind pressures. Section 4 presents the wind-tunnel and full-scale tests that can be carried out for the measurement of wind surface pressures on greenhouse structures. Section 5 compares the wind pressure coefficients provided by Kwon et al. [7] for evenand peach-type single-span greenhouses based upon wind tunnel tests with those stemming from EN 13031-1 requirements. Section 6 summarizes recent comparative results for multi-span greenhouses. Section 7 gives some concluding remarks.

\section{EN 13031-1 Provisions}

\subsection{General}

The structural design of greenhouses is generally based on the Eurocode principles. Following these design principles together with the corresponding requirements for actions [6], structural resistance and stability, serviceability, and durability are ensured. The EN 13031-1 European Standard [3] gives specific rules and information for the structural design and construction of greenhouses to enable adequate structural safety. More specifically, non-contradictory, complementary information is provided to address the specific requirements, functions, and forms of commercial production greenhouses, which distinguish them from ordinary buildings. A distinguishing functional requirement is the optimization of solar radiation transmission to create and maintain an optimal environment for the growth of plants 
and crops. This has implications on the form and structural design of commercial greenhouses [3]. This standard does not cover fire resistance-related aspects.

Following EN 13031-1, commercial production greenhouses are classified according to: (a) the tolerance to frame displacement of the cladding system (that is, the outer skin of roof and wall attached to the structural framework of the greenhouse, which is made of panels of glass or plastic sheets or of plastic film and may include further metal components, such as cladding bars, ridge bar, and gutter); and (b) the design working life of the structure. Greenhouses with cladding system not tolerant to frame displacements are designated as Class A, while greenhouses with cladding system tolerant to frame displacements are designated as Class B. Based on the structure's design working life, which is small compared with buildings intended for human occupancy, greenhouses are classified as shown in Table 1.

Table 1. Greenhouse classification according to EN 13031-1 [3].

\begin{tabular}{|c|c|c|c|}
\hline $\begin{array}{l}\text { Greenhouse class } \\
\text { Reliability class }\end{array}$ & $\begin{array}{l}\mathrm{A} 15^{1} \text { and } \mathrm{B} 15^{2} \\
\mathrm{RC}^{3}\end{array}$ & $\begin{array}{c}\mathrm{B} 10^{2} \\
\mathrm{RC}^{4}\end{array}$ & $\begin{array}{c}\mathrm{B}^{2} \\
\mathrm{RC} 0^{4}\end{array}$ \\
\hline $\begin{array}{l}\text { Reference period for } \\
\text { actions } \mathrm{n} \text { in years }\end{array}$ & 15 & 10 & 5 \\
\hline
\end{tabular}

Moreover, two reliability classes are defined, one for Type-A and Type-B greenhouse classes with a design working life of at least 15 years, and one for Type-B greenhouse classes with a minimum design working life of 10 or 5 years. It is worth noting that for commercial production greenhouses the consequences of failure are lower than for buildings intended for human occupancy. This is true also concerning the importance for public safety, given that there is no public access and the human access is restricted to low levels of authorized personnel (in number and duration). Furthermore, the potential economic loss is limited to the owner, and typically there is no environmental impact.

\subsection{Wind Loads}

Characteristic values of wind actions are calculated in accordance with EN 1991-1-4 [6]. Therefore, wind pressure acting on the external surfaces, denoted by $w_{e}$, should be calculated as follows

$$
w_{e}=q_{p}\left(z_{e}\right) \cdot c_{p e},
$$

where $q_{p}\left(z_{e}\right)$ is the peak velocity pressure, $z_{e}$ is the reference height for the external pressure and $c_{p e}$ is the pressure coefficient for the external pressure (see Annex B in [3]).

The wind pressure acting on the internal surfaces, denoted by $\mathrm{w}_{\mathrm{i}}$, should be calculated as follows

$$
w_{i}=q_{p}\left(z_{i}\right) \cdot c_{p i}
$$

where $q_{p}\left(z_{i}\right)$ is the peak velocity pressure, $z_{i}$ is the reference height for the internal pressure and $c_{p i}$ is the pressure coefficient for the internal pressure (see Annex B in [3]).

With regard to peak velocity pressures in Equations (1) and (2), it should be noted that they are based on mean wind velocities at height $\mathrm{z}$ above the terrain, which in turn depend on the basic wind velocity as defined in EN 1991-1-4, i.e. the 10-min mean wind velocity at 10-m height above ground of terrain category II. For the state-of-the-art methods to estimate peak wind pressures, the reader is referred to Gavanski and Cook [8].

The EN 13031-1 European Standard provides complementary information to take into account special properties of greenhouse structures, such as:

- Reference height $\left(z_{e}, z_{i}\right)$ for greenhouses 
- Size effect on the gust wind response of greenhouses with a large floor area

- Correlation of windward-leeward pressures for walls and greenhouse roofs

- Aerodynamic pressure coefficients (see below) for special greenhouse structures with smooth cladding, for example film, plastic, or glass

- More specifically, EN 13031-1 provides:

- External pressure coefficients $c_{p e}$ for greenhouses Type A and Type B with pitched roofs and roof angles between $20^{\circ}$ and $30^{\circ}$

- External pressure coefficients $c_{p e}$ for greenhouses Type B with arched roofs

- Internal pressure coefficients $c_{p i}$ to be used together with the external coefficients

- Surface friction coefficients $c_{f r}$ for the greenhouse cladding

According to EN 13031-1, for determining the aerodynamic coefficients, the roof angle $\alpha$ in case of a pitched roof or the radial angle $\theta$ in case of an arched roof are required, as well as the geometric aspect ratios $\mathrm{h} / \mathrm{s}, \mathrm{h} / \mathrm{w}$, and $\mathrm{h} / \mathrm{l}$ with the following symbols (Figure 2 ):

- $\alpha=$ Roof angle of a pitched roof

- $\theta=$ Radial angle of an arched roof

- $\mathrm{h}=$ Reference height for pressure coefficients, with $\mathrm{h}=\max \left(\mathrm{h}_{\mathrm{e}} ; 0,75 \mathrm{H}\right)$

- $h_{\mathrm{g}}=$ Gutter height measured from ground level

- $\mathrm{h}_{\mathrm{e}}=$ Eaves height measured from ground level

- $\mathrm{H}=$ Ridge height measured from ground level

- $\mathrm{s}=$ Width of one single roof span

- $\quad \mathrm{w}=$ Total width of the greenhouse with $\mathrm{w}=\mathrm{n}_{\mathrm{S}} \cdot \mathrm{s}$ (total width of a multi-span roof)

- $1=$ Overall length of the greenhouse in the direction parallel to the ridge

Particular attention with detailed tables is paid to: (a) greenhouses Type A and Type B with pitched roofs (single- and multi-span roofs); and (b) greenhouses type B with arched roofs (singleand multi-span roofs-with and without eaves). Figure 2 shows the surfaces used for defining global pressure coefficients, which are considered in the comparative study of Section 5, and Tables 2 and 3 provide the corresponding expressions of pressure coefficients. Before moving to the comparative study, however, it is instructive to introduce the computational methods (Section 3), experiments (Section 4.1), and field tests (Section 4.2) used to compute or measure wind pressures on greenhouse structures. 

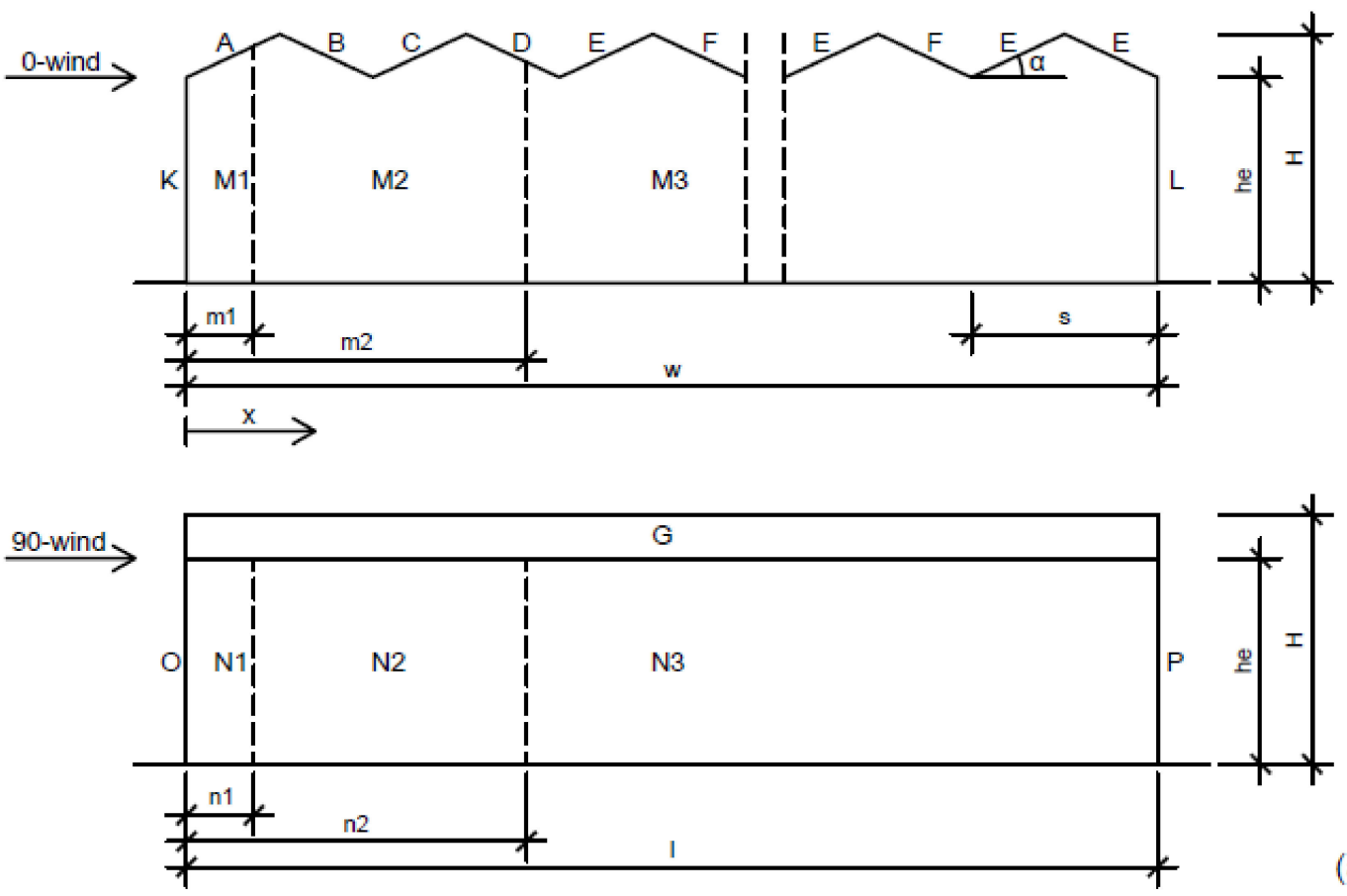

(a)
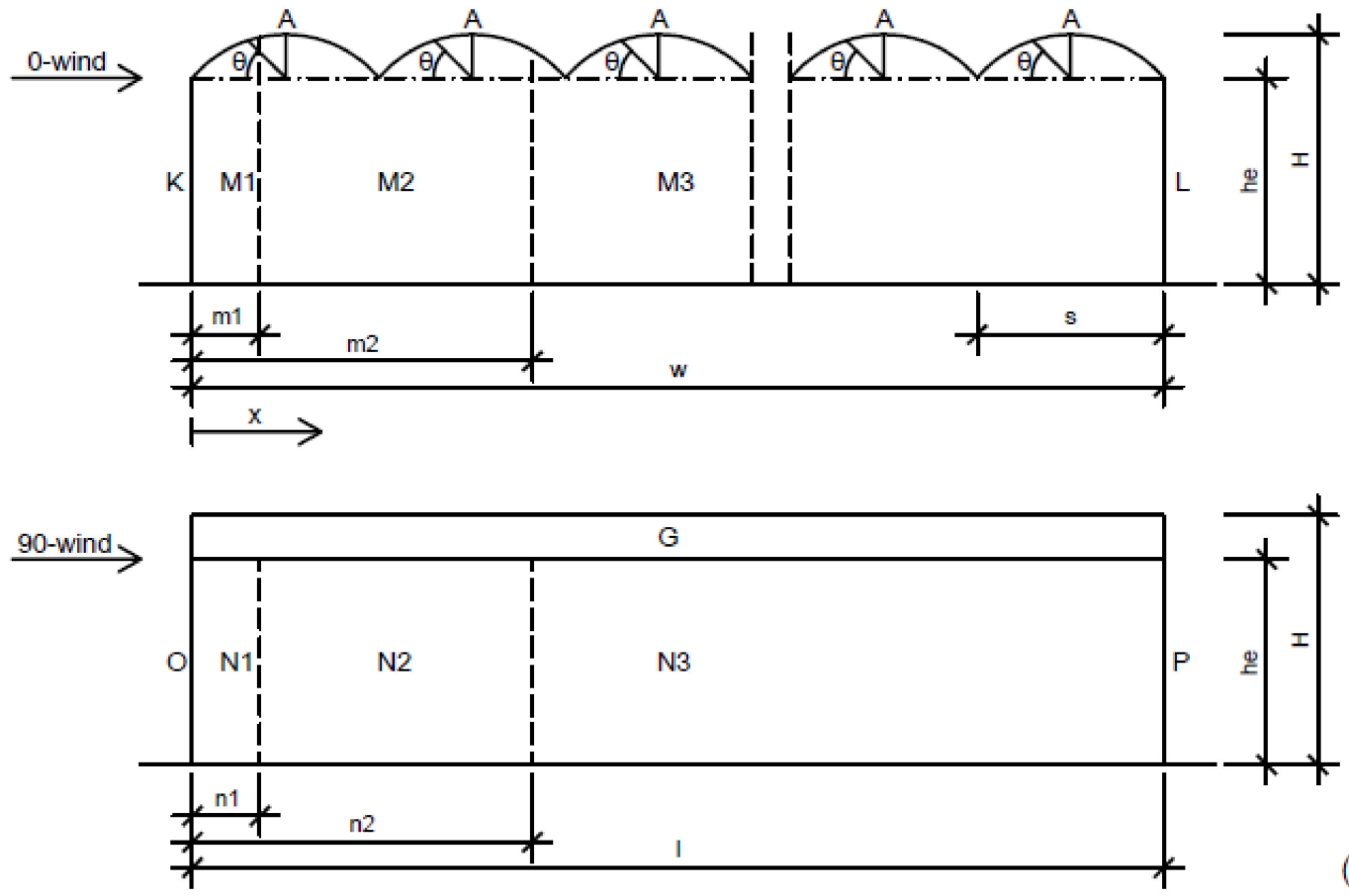

(b)

Figure 2. Zones for global pressure coefficients for walls and single- and multi-span roofs of greenhouses with (a) pitched and (b) arched roofs and eaves, according to EN 13031-1 [3] $\left(\mathrm{m}_{1}=0,4 \mathrm{~h} \leq 0,2 \mathrm{l} ; \mathrm{n}_{1}=0,4 \mathrm{~h}\right.$ $\left.\leq 0,2 \mathrm{w} ; \mathrm{h}=\max \left(\mathrm{h}_{\mathrm{e}} ; 0,75 \mathrm{H} ; \mathrm{m}_{2}=2 \mathrm{~h} \leq \mathrm{l} ; \mathrm{n}_{2}=2 \mathrm{~h} \leq \mathrm{w}\right)\right)$. 
Table 2. Global pressure coefficients for walls and single- and multi-span roofs of greenhouses with pitched roofs (Figure 2a) according to EN 13031-1 [3].

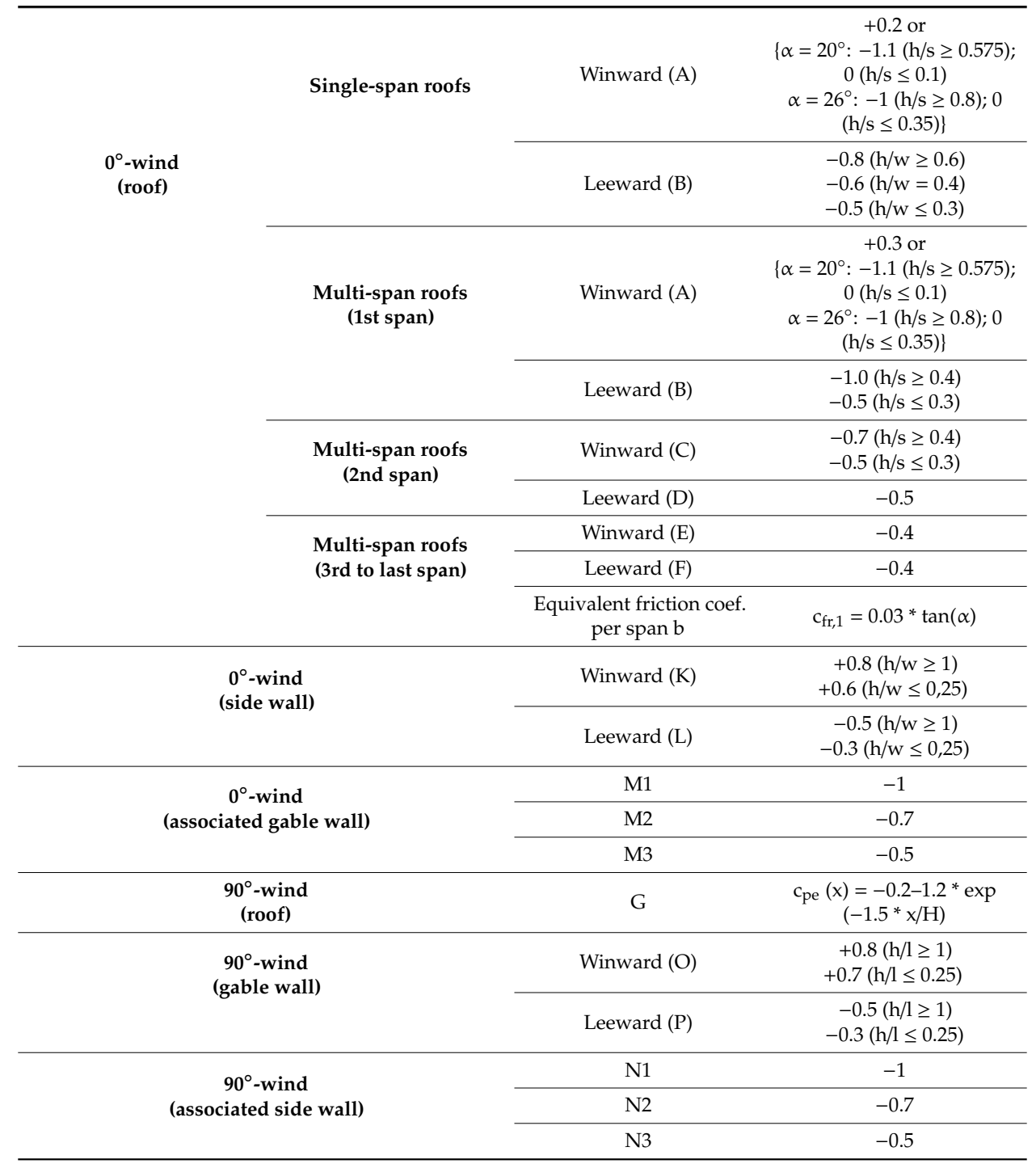


Table 3. Global pressure coefficients for walls and single- and multi-span roofs of greenhouses with arched roofs (Figure 2b) according to EN 13031-1 [3].

\begin{tabular}{|c|c|c|c|c|}
\hline \multirow{5}{*}{$\begin{array}{l}0^{\circ} \text {-wind } \\
\text { (roof) }\end{array}$} & \multirow{5}{*}{ 1st span } & \multirow{5}{*}{ A } & $\theta=$ Gutter to $55^{\circ}$ & +0.3 \\
\hline & & & $\begin{array}{c}\theta=55^{\circ} \text { to } 115^{\circ} \\
\text { (single-span) }\end{array}$ & $\begin{array}{l}-1.0 \text { or } \\
-1.2 \text { for flat arches with }(\mathrm{H}-\mathrm{he}) / \mathrm{s}<0.2 \\
\text { and plastic film unstrained against } \\
\text { uplifting over the ridge }\end{array}$ \\
\hline & & & $\begin{array}{l}\theta=55^{\circ} \text { to } 70^{\circ} \\
\text { (multi-span) }\end{array}$ & -1.0 \\
\hline & & & $\begin{array}{c}\theta=70^{\circ} \text { to } 115^{\circ} \\
\text { (multi-span) }\end{array}$ & $\begin{array}{c}-1.0 \text { or }-1.2 \text { for flat arches with } \\
(\mathrm{H}-\mathrm{he}) / \mathrm{s}<0.2 \text { and plastic film } \\
\text { unstrained against uplifting over the } \\
\text { ridge }\end{array}$ \\
\hline & & & $\theta=115^{\circ}$ to Gutter & -0.4 \\
\hline \multirow{3}{*}{$\begin{array}{l}0^{\circ} \text {-wind } \\
\text { (roof) }\end{array}$} & \multirow{3}{*}{ 2nd span } & \multirow{3}{*}{ A } & $\theta=$ Gutter to $80^{\circ}$ & -0.2 \\
\hline & & & $\theta=80^{\circ}$ to $100^{\circ}$ & -0.9 \\
\hline & & & $\theta=100^{\circ}$ to Gutter & -0.3 \\
\hline $\begin{array}{l}0^{\circ} \text {-wind } \\
\text { (roof) }\end{array}$ & $\begin{array}{l}\text { 3rd and subsequent } \\
\text { spans }\end{array}$ & A & $\theta=$ Gutter to $55^{\circ}$ & $60 \%$ of 2 nd span \\
\hline \multirow{2}{*}{$\begin{array}{l}0^{\circ} \text {-wind } \\
\text { (side wall) }\end{array}$} & \multicolumn{2}{|c|}{ Winward (K) } & \multicolumn{2}{|r|}{+0.6} \\
\hline & \multicolumn{2}{|c|}{ Leeward (L) } & \multicolumn{2}{|r|}{$\begin{array}{l}-0.6(h / w \geq 0.6) \\
-0.3(h / w \leq 0.4)\end{array}$} \\
\hline \multirow{3}{*}{$\begin{array}{c}0^{\circ} \text {-wind } \\
\text { (associated gable wall) }\end{array}$} & \multicolumn{2}{|c|}{ M1 } & \multicolumn{2}{|r|}{-1} \\
\hline & \multicolumn{2}{|c|}{ M2 } & \multicolumn{2}{|r|}{-0.7} \\
\hline & \multicolumn{2}{|c|}{ M3 } & \multicolumn{2}{|r|}{-0.5} \\
\hline $\begin{array}{l}90^{\circ} \text {-wind } \\
\text { (roof) }\end{array}$ & \multicolumn{2}{|c|}{ G } & \multicolumn{2}{|c|}{$\begin{array}{l}\text { Single-span: } c_{p e}(x)=-0.2-1.2 * \exp (-1.5 * x / H) \\
\text { Multi-span: } c_{p e}(x)=-0.2-1.3 * \exp (-1.5 * x / H)\end{array}$} \\
\hline \multirow{2}{*}{$\begin{array}{l}90^{\circ} \text {-wind } \\
\text { (gable wall) }\end{array}$} & \multicolumn{2}{|c|}{ Winward $(\mathrm{O})$} & \multicolumn{2}{|r|}{+0.7} \\
\hline & \multicolumn{2}{|c|}{ Leeward $(\mathrm{P})$} & \multicolumn{2}{|r|}{-0.3} \\
\hline \multirow{3}{*}{$\begin{array}{l}90^{\circ} \text {-wind } \\
\text { (associated side wall) }\end{array}$} & \multicolumn{2}{|c|}{ N1 } & \multicolumn{2}{|r|}{-1} \\
\hline & \multicolumn{2}{|c|}{ N2 } & \multicolumn{2}{|r|}{-0.7} \\
\hline & \multicolumn{2}{|c|}{ N3 } & \multicolumn{2}{|r|}{-0.5} \\
\hline
\end{tabular}

\section{Computational Fluid Dynamics (CFD) Modeling}

Computational fluid dynamics (CFD) is a field of fluid mechanics which uses numerical analysis to solve fluid flows problems. Simulations model the free-stream flow of fluids as well as the fluid-surface interaction defined by proper boundary conditions. Initial validation of CFD software is usually performed with the aid of experimental observations, such as wind tunnels. CFD is applied to a broad range of problems in engineering, with wind loads constituting one of them.

Many software packages have been developed over the last decades for solving fluid dynamics problems, and thus numerous CFD simulations have been performed to study 3D flow in greenhouse structures. Specifically, CFD is used to study: (a) greenhouse ventilation, that is airflow and climate inside greenhouses, associated with efficiency of cultural operations, environmental impact and crop development; and (b) greenhouse wind loads, that is wind pressures for structural design.

With regard to wind pressures, on which the present paper focuses, the literature is rich of papers presenting CFD models and comparing CFD simulation results with experimental or field measurements. This is true not only for greenhouses, but for various types of structures (see, for example, Fouad et al. [9] and Gomes et al. [10]), including low-rise structures with similar geometrical characteristics to greenhouses. Although CFD models require many elements and computational resources, and moreover computational results are often highly mesh dependent thus requiring parametric studies, CFD models are indispensable and have many advantages: (a) they can provide insight into wind loads for structures not covered by design codes; (b) they can be used to compensate for insufficient wind tunnel test data (e.g., to estimate pressure distributions on surfaces in the case of few measuring points); and (c) they are easier, faster, less costly, more flexible, and more feasible to perform compared with wind tunnel or field tests. However, it should not be ignored that CFD models require a detailed validation with existing experimental or field data, while sometimes, e.g. 
when studying less typical/more complicated problems, validating experiments should be designed and conducted. A brief literature review is performed in the following of some recent works on the topic: (a) to show the wide use of CFD for calculating wind pressures in greenhouses; and (b) to highlight that, despite the high complexity of the physical problem, CFD models can be calibrated to reproduce experimental results successfully. Theoretical background and computational algorithms of CFD are be addressed here; the reader is referred to fluid mechanics textbooks.

Hwang and Lee [11] performed CFD simulations to determine the wind pressure coefficients of greenhouses in a reclaimed land. The accuracy of the CFD model was validated and the proper mesh size was chosen using own wind tunnel test measurements.

Kuroyanagi [12] investigated the air leakage from greenhouses, which affects heating load, carbon dioxide supply, and wind loads on greenhouses. The study estimated greenhouse leakage rate by means of: (a) CFD simulations of the external pressure coefficients of the greenhouse cladding; and (b) modeling of airflow through leakage paths on the greenhouse walls. The simulation results of the leakage rate were validated using experimental results from two greenhouses with the same structure but with different orientation. The results indicate that strong transverse wind created lower leakage rate and internal pressure coefficient. These outcomes highlight the necessity of further studies on establishing a link between wind direction, internal pressure, and amount of greenhouse leakage.

More recently, Kim et al. [13] firstly developed a CFD model considering wind tunnel measurements to predict the external pressure coefficients of greenhouses. Initially, wind pressure distributions of even-span- and peach-type greenhouses were measured through wind tunnel tests (see Kwon et al. [7]) and the results were compared with CFD-computed results. The reliability of the CFD model was improved by taking into consideration various experimental conditions. The proposed CFD model was proved to be very effective in predicting external pressure coefficients of greenhouses, and is expected, according to the authors, to enable the evaluation of $c_{p e}$ values in an attempt to establish newly modified greenhouse design standards. Their results could serve as guidelines for evaluating CFD models.

Then, Kim et al. [14] estimated the $c_{p e}$ values of multi-span greenhouses that are typical in South Korea, e.g., wide-span-, Venlo-, and 1-2W-type greenhouses, considering the above-mentioned CFD model. Specifically, the CFD-computed $c_{p e}$ values were analyzed accounting for the wind directions, number of spans, and greenhouse design factors (e.g., the roof slope and roof curvature radius). The analysis results led to suggestion of the CFD-computed $c_{p e}$ values for use in structural and cladding design of multi-span greenhouses. IThe maximum $c_{p e}$ values were investigated for cladding design taking into account all wind directions. It should be noted, however, that Kim et al. $[13,14]$ provided mean values for external pressure coefficients and information on peak values is missing in the paper.

As already mentioned, CFD simulations are strongly associated with laboratory and field measurements. To this end, wind-tunnel and full-scale tests are introduced in the following section.

\section{Wind-Tunnel and Full-Scale Tests}

\subsection{Wind-Tunnel Tests}

Modeling in wind tunnels is extensively used in experimental aerodynamics. External and internal flows in greenhouses involve complex interactions, particularly between atmospheric and greenhouse boundary layers. More specifically, viscous effects manifest themselves at the surfaces and atmospheric boundary layer characteristics and magnify outside the greenhouse boundary layers [15]. As mentioned in [15]: "The range of the influence of the greenhouse boundary layer depends on the absolute scale, thus the inward and outward vent air fluxes are formed from the merging of two or more greenhouse boundary layers and the atmospheric boundary layer. Merging boundary layers may cover the whole area of the vent, so that the distributions of air mass fluxes are strongly non-uniform. In a small-scale greenhouse model (e.g. 1/16, 1/10) it is not possible to insert the anemometer sensors for measuring velocity distribution 
without influencing the flow pattern (a way to solve this problem is to install a $2 D$ particle image velocimeter)". Wind-tunnel tests are costly; time-consuming; require special laboratory equipment, experienced personnel, and careful design and execution; and incorporate the difficulty to reproduce Reynolds numbers. However, they provide the most reliable data for wind pressure distributions, serving as benchmark for numerical analyses as well as for code provisions. Some characteristic papers addressing greenhouse structures are mentioned here.

Moriyama et al. [16] carried out wind tunnel tests to evaluate wind pressure coefficients in a pipe-framed greenhouse whose shape consists of two or more curvatures. The experiments were performed in an Eiffel-type wind tunnel at the National Institute for Rural Engineering, using a 1/20 scale model with length to width ratio of 8.3 in a turbulent boundary layer. it is worth noting that only time-averaged values are discussed in the paper.

Yang et al. [17] conducted wind tunnel tests in the NH-2 wind tunnel at Nanjing University of Aeronautics and Astronautics (NH-2 is a closed-circuit low-speed wind tunnel, $20 \mathrm{~m}$ long, $3 \mathrm{~m}$ wide, and $2.5 \mathrm{~m}$ high, with a maximum continuously adjustable wind speed of $90 \mathrm{~m} / \mathrm{s}$ ). They investigated wind pressure coefficients and their distribution on the surfaces of: (a) a single-span plastic greenhouse; and $(b)$ a solar greenhouse, using $1 / 6$ scale models. Wind pressures were measured at several different points on the greenhouse model surfaces, considering various wind directions. Moreover, the authors derived the critical wind speeds at which damage occurred on the surfaces of the greenhouse structures considered.

Kwon et al. [7] measured the wind pressure coefficients on single-span greenhouses in an Eiffel-type large-scale wind tunnel (TESolution Co., Anseong City, Gyenonggi-do, Korea). The target single-span greenhouses included four types that are typical in South Korea (Figure 3): (a) even-span; (b) three-quarter; (c) peach; and (d) mono-span. The test section of the experimental wind tunnel had a width of $8.0 \mathrm{~m}$, a height of $2.5 \mathrm{~m}$, and a length of $23.2 \mathrm{~m}$. The turntable of the test section has a diameter of $3.0 \mathrm{~m}$ and it can revolve \pm 270 degrees for measurements. This facilitated simulation of alternating wind directions. Moreover, three suction-type blowers with a diameter of $1.5 \mathrm{~m}$ were installed. The blowers produced wind speeds between 0.3 and $11.5 \mathrm{~m} / \mathrm{s}$ in the test section. The authors concluded that detailed consideration of both the structural and the cladding design is important for ensuring structural safety and economically stable operation of greenhouses subject to strong wind loads. The results of Kwon et al. [7] are analyzed in Section 5.

Bronkhorst et al. [18] conducted wind tunnel experiments in the open-circuit atmospheric boundary layer wind tunnel of TNO in the Netherlands, which are further analyzed in Section 6. It is worth noting here that, contrary to Kim et al. [13,14], Bronkhorst et al. [18] provide detailed information on both mean and peak pressure coefficients. 

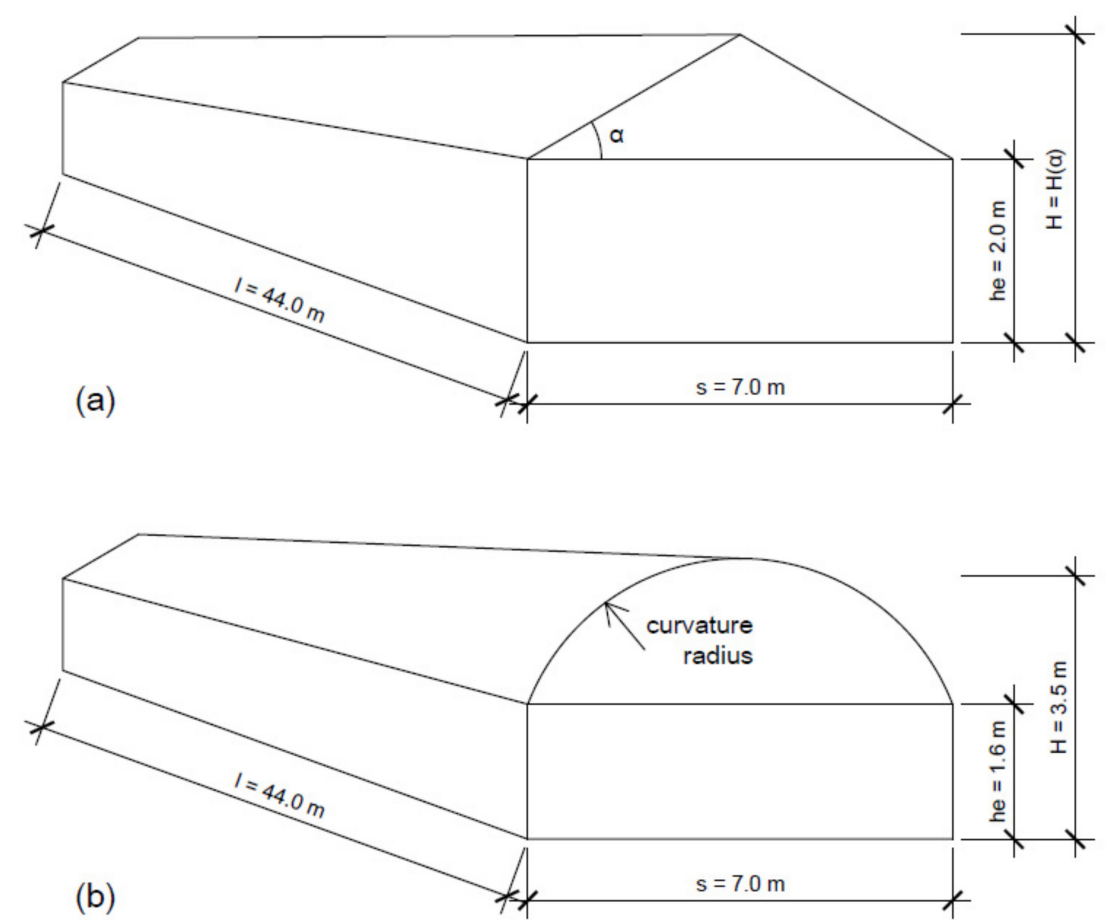

Figure 3. Schematic diagram of two target single-span greenhouses investigated in [7]: (a) even-span type; and (b) peach type.

\subsection{Full-Scale Tests}

Apart from numerical models and wind tunnel tests, full-scale tests can also be carried out to measure wind loads on greenhouses. This section presents a concise literature review on the topic. A critical review of many of them was included by Bronkhorst et al. [18]. All tests mentioned have been conducted in the United Kingdom, where wind constitutes "the single most destructive force to which film-plastic clad tunnel-type greenhouses are subjected" [19], in the framework of research programs performed at the National Institute of Agricultural Engineering.

Hoxey and Wells [20] presented results of a quite limited program of wind pressure measurements on a film clad inflated roof greenhouse. Measurements were made on the full-scale structure under natural wind conditions.

Wells and Hoxey [21] made measurements on five glasshouse types of different shapes, under natural wind conditions and an overall range of direction above $90^{\circ}$.

Hoxey and Richardson [22,23] made full-scale measurements of the surface pressures on film plastic clad greenhouses under natural wind conditions. The work described in these papers was the most detailed full-scale study of the wind loads on film plastic clad greenhouses. The results provide detailed information with regard to the distribution of wind loads. The data were summarized into a coding format as pressure coefficients for use in the context of the general design procedure of CP3 (i.e., Basic Data for the Design of Buildings, Ch. 5, Loading, Part 2, Wind loads, British Standard Institution, London, UK, 1972). The validity of the above was restricted to the range of certain singleand multi-span shapes (as shown in the paper).

Richardson and Westgate [24] designed a full-scale experiment to compare loading data from a single span tunnel-type greenhouse with those stemming from a $2 \mathrm{D}$ finite element model. To this end, they built a single-span 6.3-m-wide film plastic clad greenhouse at the National Institute of Agricultural Engineering, on an exposed site with a fetch of $600 \mathrm{~m}$ for winds. The load distributions from measurements and calculations agreed sufficiently well and thus validated the calculation method. Therefore, the authors concluded that, for design purposes, wind loads can generally be considered as quasi-static. 
Following the previous study, Richardson [25] presented full-scale measurements of the surface pressures on sheltered and unsheltered tunnel-type greenhouses, under natural wind flow conditions, considering again a film-plastic clad greenhouse sited in open country (i.e., with no obstructions within $600 \mathrm{~m}$ of the face exposed to the wind).

\section{Comparison Between EN 13031-1-Provided and Kwon et al. (2016)-Provided Wind Pressure Coefficients for Single-Span Greenhouses}

The design standards, numerical methods, experiments, and field tests used to estimate wind pressures on greenhouse structures are discussed above. Therefore, we can now move to the comparison of code provisions with measurement data to evaluate some recent research outcomes, which support that standards may not always be conservative in terms of pressure coefficients.

\subsection{General}

The most recent studies on wind loads for greenhouse structures are those of Kim et al. [13,14]. The aim of these studies was to evaluate, using CFD, the external pressure coefficients of single- and multi-span, pitched and arched, greenhouses for structural and cladding design. To this end, the authors built a CFD model, which was first calibrated using the wind tunnel measured coefficients presented by Kwon et al. [7]. Then, they used this model to calculate the pressure coefficients for multi-span greenhouses. The measured pressure coefficients presented in [7] thus constitute fundamental point of these studies. Experiments were performed in an Eiffel-type large-scale wind tunnel in Korea. The size of the test section of the experimental wind tunnel was $8.0 \mathrm{~m}$ wide, $2.5 \mathrm{~m}$ high, and $23.2 \mathrm{~m}$ long, and the geometric similarity was set to $1 / 20$.

Given that the authors did not include any comparison in their studies with greenhouse design standards, but concluded that "these suggested results could be used to establish newly modified greenhouse design standards" [14] and that "an update of conventional greenhouse standards has been required to reflect the current situations" [7], this paper aims to compare the values provided in [7] with those suggested by the EN 13031-1 Standard. As explained in Section 2, EN 13031-1 explicitly addresses only symmetric pitched and arched roofs. For this reason, out of the four target single-span greenhouses included in [7], only the even-span- (Figure 3a) and the peach-type (Figure 3b) greenhouses are considered here. Moreover, since this paper focuses on structural design, only the so-called global external pressure coefficients were evaluated. Table 4 summarizes the geometric characteristics of the single-span greenhouses considered. As can be seen, six angles were considered for the pitched roof and six curvature radii for the arched roof.

Table 4. Geometric characteristics of the single-span greenhouses under consideration (after [7]).

\begin{tabular}{|c|c|c|}
\hline Geometric Variable & Pitched Roof & Arched Roof \\
\hline Roof angle of a pitched roof, $\alpha\left(^{\circ}\right)$ & $22,24,26,28,30,32$ & - \\
\hline Curvature radius of roof $(\mathrm{m})$ & - & $4,4.5,5,5.5,6,6.5$ \\
\hline Eaves height measured from ground level, he $(\mathrm{m})$ & 2 & 1.6 \\
\hline Width of one single roof span, $\mathrm{s}(\mathrm{m})$ & 7 & 7 \\
\hline $\begin{array}{l}\text { Overall length of the greenhouse in the direction parallel to } \\
\text { the ridge, } 1(\mathrm{~m})\end{array}$ & 44 & 44 \\
\hline Ridge height measured from ground level, $\mathrm{H}=f(\alpha)(\mathrm{m})$ & $3.41-4.19$ & 3.5 \\
\hline $\begin{array}{l}\text { Reference height for pressure coefficients, } h=\max \left(h_{e}\right. \\
0.75 H)(m)\end{array}$ & $2.56-3.14$ & 2.63 \\
\hline
\end{tabular}

Global external pressure coefficients of greenhouses correspond to particular surfaces, depending on the direction of the wind. A $0^{\circ}$-wind is assumed here as wind in the direction perpendicular to the ridge, while $90^{\circ}$-wind is assumed here as wind in the direction parallel to the ridge (see Figures 4 and 5). 

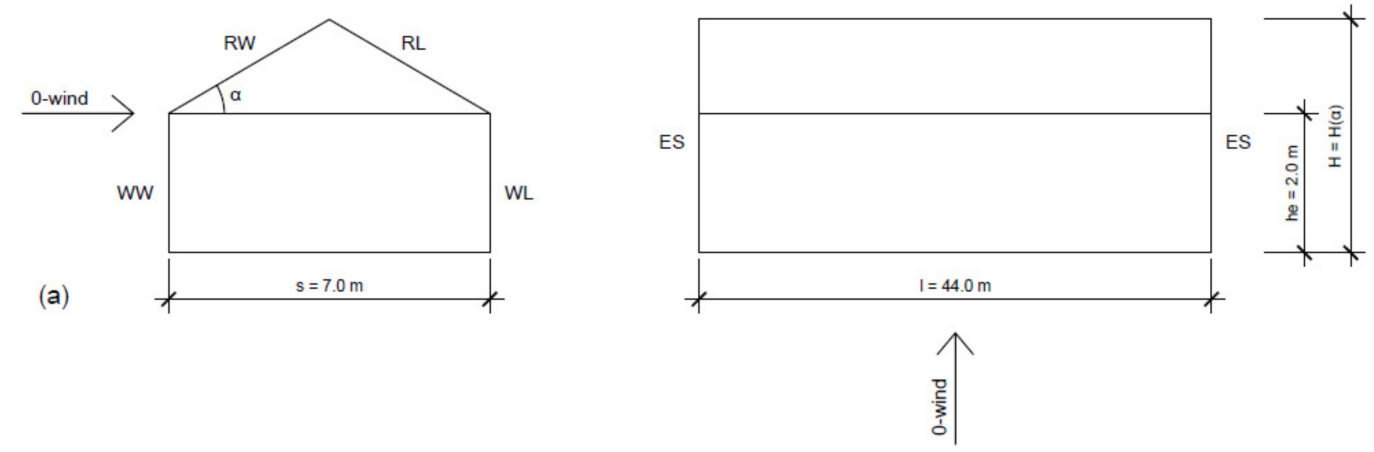

(b)
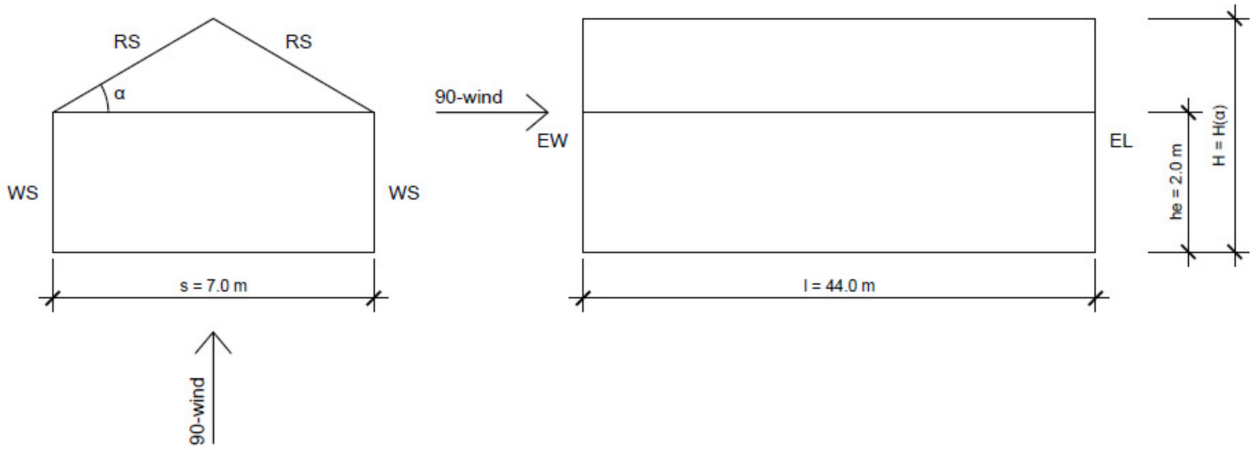

Figure 4. Definition of surfaces according to [7] for global pressure coefficients of single-span greenhouse with pitched roof, considering: (a) $0^{\circ}$-wind; and (b) $90^{\circ}$-wind.
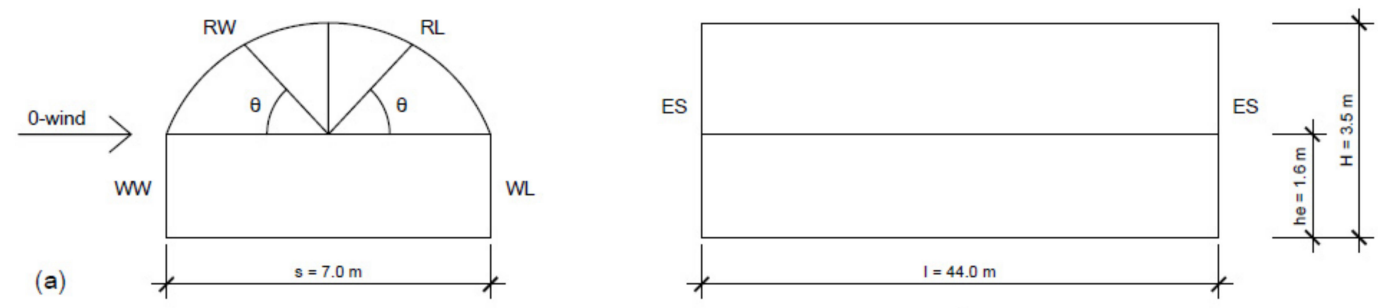

(b)
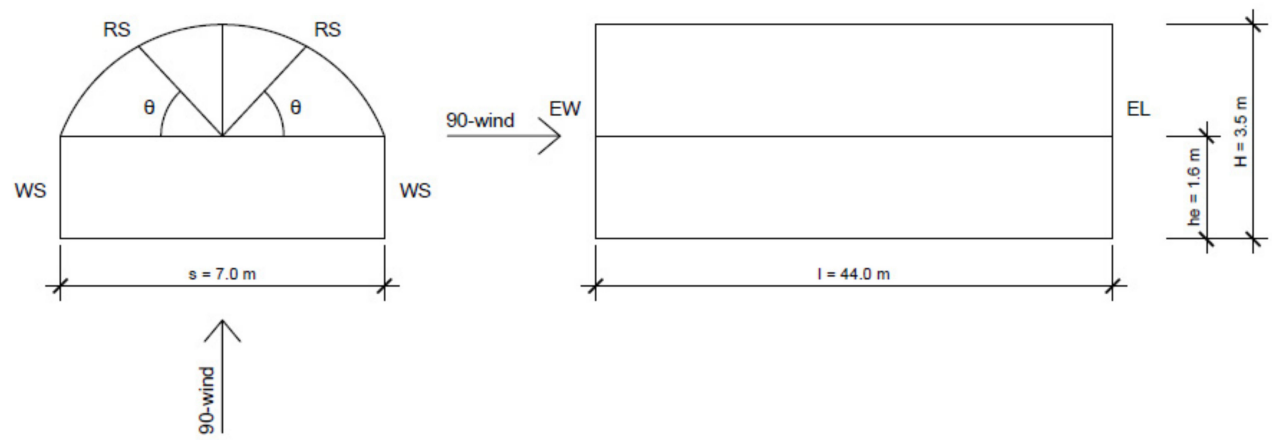

Figure 5. Definition of surfaces according to [7] for global pressure coefficients of single-span greenhouse with arched roof, considering: (a) $0^{\circ}$-wind; and (b) $90^{\circ}$-wind.

Following the notation of Kwon et al., which is analogous to that of EN 13031-1 (see Figure 2) but uses different symbols, the following surfaces are considered:

- For the $0^{\circ}$-wind (see Figures $4 \mathrm{a}$ and $5 \mathrm{a}$ ), the wall surface on the windward side is represented by WW (Wall Windward) and that on the leeward side by WL (Wall Leeward). The roof surface on the windward side is represented by RW (Roof Windward) and that on the leeward side by 
RL (Roof Leeward). Both walls located at the end parts of the greenhouse are represented by ES (End Side).

- For the $90^{\circ}$-wind (see Figures $4 \mathrm{~b}$ and $5 \mathrm{~b}$ ), the surfaces of the side walls and roof walls are represented by WS and RS, respectively. The end wall on the windward side is represented by EW and the end wall on the leeward side is represented by EL.

\subsection{Pitched Roof Greenhouses}

Table 5 gives the pressure coefficients provided by Kwon et al. for the even-span greenhouses tested, and Table 6 gives the corresponding values suggested in EN 13031-1. According to the European Standard, global external pressure coefficients for the walls and roofs of greenhouses with pitched roofs are given in Table 2 and depend on the roof angle $\alpha$ and the ratios $\mathrm{h} / \mathrm{s}$ and $\mathrm{h} / \mathrm{l}$. For intermediate values of $\alpha, h / s$, and $h / l$, linear interpolation between values of pressure coefficients with the same sign was performed. Figure 6 shows graphically the difference between average external pressure coefficients for wall and roof surfaces (of all the roof slopes) provided by Kwon et al. and EN 13031-1 European Standard, considering: (a) $0^{\circ}$-wind; and (b) $90^{\circ}$-wind. The results presented lead to the following observations:

- For the $0^{\circ}$-wind, the Kwon et al. pressure coefficients for the wall and roof surfaces on the leeward side (WL and RL) are higher than those suggested in EN 13031-1. On the other hand, EN 13031-1 coefficients for the roof surfaces on the windward side (RW) are higher than those in Kwon et al. Finally, the pressure coefficients for the wall surfaces on the windward side (WW) and at the end parts (ES) are practically the same.

- For the $90^{\circ}$-wind, EN 13031-1 systematically leads to higher pressure coefficients than Kwon et al., particularly concerning the surfaces of the side walls (WS).

Table 5. Global external pressure coefficients provided by Kwon et al. [7] for single-span pitched roof greenhouses.

\begin{tabular}{|c|c|c|c|c|c|c|c|}
\hline \multirow[t]{3}{*}{ Wind Direction $\left({ }^{\circ}\right)$} & \multirow[t]{3}{*}{ Surface } & \multicolumn{6}{|c|}{ Wind Pressure Coefficient } \\
\hline & & \multicolumn{6}{|c|}{ Roof Slope a $\left({ }^{\circ}\right)$} \\
\hline & & 22 & 24 & 26 & 28 & 30 & 32 \\
\hline \multirow[t]{5}{*}{0} & WW & 0.64 & 0.61 & 0.57 & 0.56 & 0.53 & 0.50 \\
\hline & WL & -0.67 & -0.68 & -0.71 & -0.72 & -0.71 & -0.72 \\
\hline & RW & -0.31 & -0.21 & -0.18 & -0.10 & -0.04 & 0.03 \\
\hline & RL & -0.76 & -0.74 & -0.79 & -0.76 & -0.75 & -0.73 \\
\hline & ES & -0.98 & -0.94 & -1.00 & -0.98 & -0.97 & -0.96 \\
\hline \multirow{4}{*}{90} & WS & -0.07 & -0.07 & -0.09 & -0.09 & -0.09 & -0.10 \\
\hline & RS & -0.10 & -0.10 & -0.12 & -0.12 & -0.12 & -0.12 \\
\hline & EW & 0.66 & 0.62 & 0.57 & 0.56 & 0.57 & 0.58 \\
\hline & EL & -0.26 & -0.23 & -0.26 & -0.25 & -0.24 & -0.22 \\
\hline
\end{tabular}

Table 6. Global external pressure coefficients suggested in EN 13031-1 European Standard [3] for single-span pitched roof greenhouses.

\begin{tabular}{cccccccc}
\hline Wind Direction $\left(^{\circ}\right.$ ) & Surface & \multicolumn{5}{c}{ Wind Pressure Coefficient } \\
\hline & & & \multicolumn{5}{c}{ Roof Slope a $\left(^{\circ}\right.$ ) } \\
\cline { 3 - 7 } & & $\mathbf{2 2}$ & $\mathbf{2 4}$ & $\mathbf{2 6}$ & $\mathbf{2 8}$ & $\mathbf{3 0}$ \\
\hline & WW & 0.63 & 0.63 & 0.64 & 0.64 & 0.65 & 0.65 \\
& WL & -0.33 & -0.33 & -0.34 & -0.34 & -0.35 & -0.35 \\
& RW & -0.42 & -0.26 & -0.10 & 0.05 & 0.21 & 0.37 \\
& RL & -0.57 & -0.58 & -0.60 & -0.61 & -0.63 & -0.65 \\
& ES & -1.00 & -1.00 & -1.00 & -1.00 & -1.00 & -1.00 \\
& WS & -1.00 & -1.00 & -1.00 & -1.00 & -1.00 & -1.00 \\
& RS & -0.20 & -0.20 & -0.20 & -0.20 & -0.20 & -0.20 \\
& EW & 0.60 & 0.60 & 0.60 & 0.60 & 0.60 & 0.60 \\
& EL & -0.30 & -0.30 & -0.30 & -0.30 & -0.30
\end{tabular}




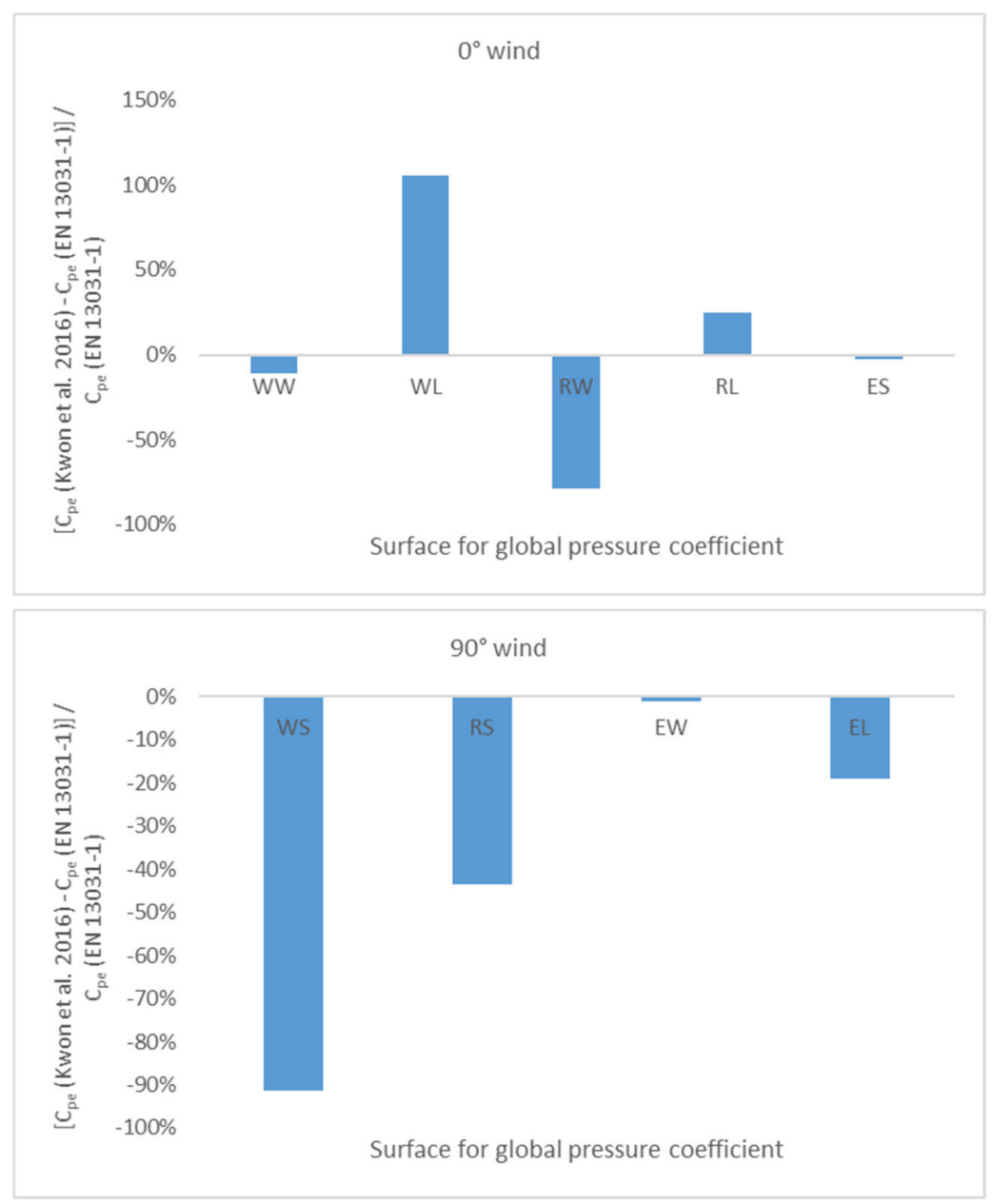

(a)

(b)

Figure 6. Difference in average external pressure coefficients for wall and roof surfaces as provided by Kwon et al. [7] and EN 13031-1 European Standard [3] for single-span pitched roof greenhouses, considering: (a) $0^{\circ}$-wind; and (b) $90^{\circ}$-wind.

Therefore, according to the present comparative results, EN 13031-1 seems to be conservative in most cases, but not always.

\subsection{Arched Roof Greenhouses}

Table 7 gives the pressure coefficients provided by Kwon et al. for the peach-type greenhouses tested, as well as the corresponding values suggested in EN 13031-1. According to the European Standard, global external pressure coefficients for the walls and roofs of greenhouses with arched roofs are given in Table 3 (as long as he/s > 0.2) and depend on the radial angle $\theta$ and the ratios $\mathrm{h} / \mathrm{s}$ and $\mathrm{H} / \mathrm{l}$. For intermediate values of $\mathrm{h} / \mathrm{s}$, linear interpolation between values of pressure coefficients with the same sign was performed. Figure 7 shows graphically the difference between average external pressure coefficients for wall and roof surfaces (of all the roof curvature radii) provided by Kwon et al. and EN 13031-1 European Standard, considering: (a) $0^{\circ}$-wind; and (b) $90^{\circ}$-wind. The results presented here follow exactly the same trend with those derived for pitched roof greenhouses, and thus lead to the same observations. 
Table 7. Global external pressure coefficients provided by Kwon et al. [7] and EN 13031-1 European Standard [3] for single-span arched roof greenhouses.

\begin{tabular}{|c|c|c|c|c|c|c|c|c|}
\hline \multirow[t]{3}{*}{ Wind Direction $\left({ }^{\circ}\right)$} & \multirow[t]{3}{*}{ Surface } & \multicolumn{7}{|c|}{ Wind Pressure Coefficient } \\
\hline & & \multicolumn{7}{|c|}{ Curvature Radius of Roof (m) } \\
\hline & & 4 & 4.5 & 5 & 5.5 & 6 & 6.5 & EN 13031-1 \\
\hline \multirow[t]{11}{*}{0} & WW & 0.50 & 0.51 & 0.52 & 0.55 & 0.55 & 0.55 & 0.60 \\
\hline & WL & -0.50 & -0.50 & -0.64 & -0.74 & -0.71 & -0.75 & -0.30 \\
\hline & $\operatorname{RW}(0<\theta<20)$ & -0.09 & -0.10 & -0.02 & 0.05 & 0.03 & 0.05 & 0.30 \\
\hline & RW $(20<\theta<40)$ & -1.09 & -0.95 & -0.79 & -0.53 & -0.46 & -0.44 & 0.30 \\
\hline & RW $(40<\theta<65)$ & -1.73 & -1.47 & -1.11 & -0.77 & -0.79 & -0.68 & -1.00 \\
\hline & RW $(65<\theta<90)$ & -1.90 & -1.77 & -1.35 & -0.83 & -0.94 & -0.80 & -1.00 \\
\hline & $\operatorname{RL}(0<\theta<20)$ & -1.76 & -1.86 & -1.36 & -0.87 & -0.90 & -0.84 & -0.40 \\
\hline & $\operatorname{RL}(20<\theta<40)$ & -1.20 & -1.04 & -1.00 & -0.82 & -0.83 & -0.81 & -0.40 \\
\hline & $\operatorname{RL}(40<\theta<65)$ & -0.61 & -0.64 & -0.81 & -0.80 & -0.79 & -0.81 & -0.40 \\
\hline & $\operatorname{RL}(65<\theta<90)$ & -0.50 & -0.55 & -0.73 & -0.79 & -0.78 & -0.81 & -1.00 \\
\hline & ES & -0.96 & -0.90 & -0.97 & -1.07 & -1.01 & -1.11 & -1.00 \\
\hline \multirow[t]{11}{*}{90} & WS & -0.17 & -0.14 & -0.13 & -0.11 & -0.13 & -0.12 & -1.00 \\
\hline & $\operatorname{RS}(0<\theta<20)$ & -0.17 & -0.16 & -0.16 & -0.15 & -0.15 & -0.15 & -0.20 \\
\hline & $\operatorname{RS}(20<\theta<40)$ & -0.19 & -0.17 & -0.18 & -0.15 & -0.16 & -0.16 & -0.20 \\
\hline & $\operatorname{RS}(40<\theta<65)$ & -0.19 & -0.17 & -0.18 & -0.15 & -0.16 & -0.16 & -0.20 \\
\hline & $\operatorname{RS}(65<\theta<90)$ & -0.20 & -0.19 & -0.19 & -0.16 & -0.17 & -0.17 & -0.20 \\
\hline & $\operatorname{RS}(90<\theta<115)$ & -0.20 & -0.20 & -0.18 & -0.16 & -0.19 & -0.17 & -0.20 \\
\hline & $\operatorname{RS}(115<\theta<140)$ & -0.16 & -0.16 & -0.14 & -0.13 & -0.14 & -0.14 & -0.20 \\
\hline & $\operatorname{RS}(140<\theta<160)$ & -0.15 & -0.15 & -0.13 & -0.12 & -0.13 & -0.13 & -0.20 \\
\hline & $\operatorname{RS}(160<\theta<180)$ & -0.13 & -0.13 & -0.12 & -0.11 & -0.12 & -0.12 & -0.20 \\
\hline & EW & 0.56 & 0.57 & 0.54 & 0.57 & 0.56 & 0.54 & 0.70 \\
\hline & EL & -0.29 & -0.29 & -0.26 & -0.26 & -0.29 & -0.27 & -0.30 \\
\hline
\end{tabular}

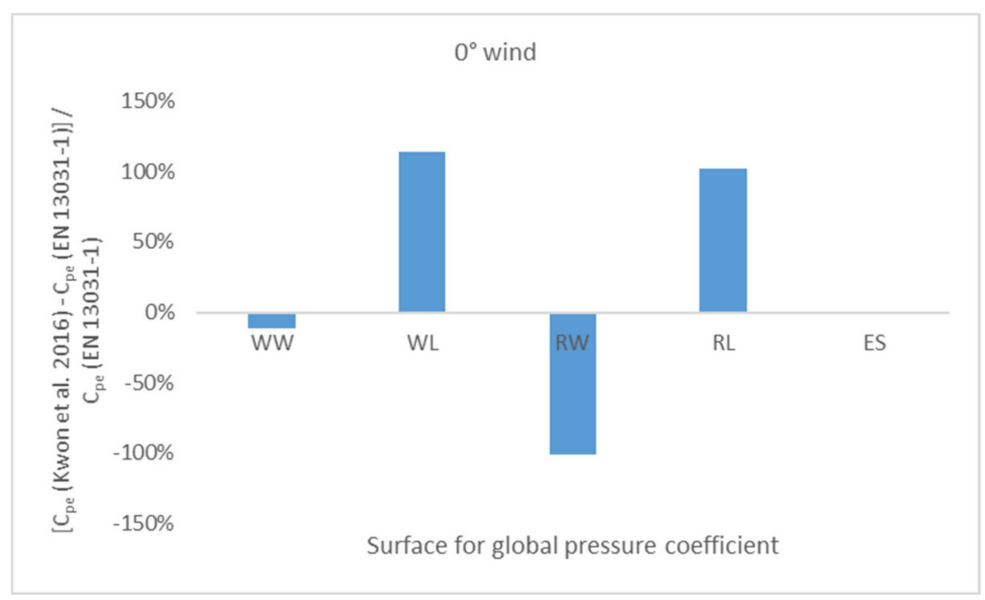

(a)

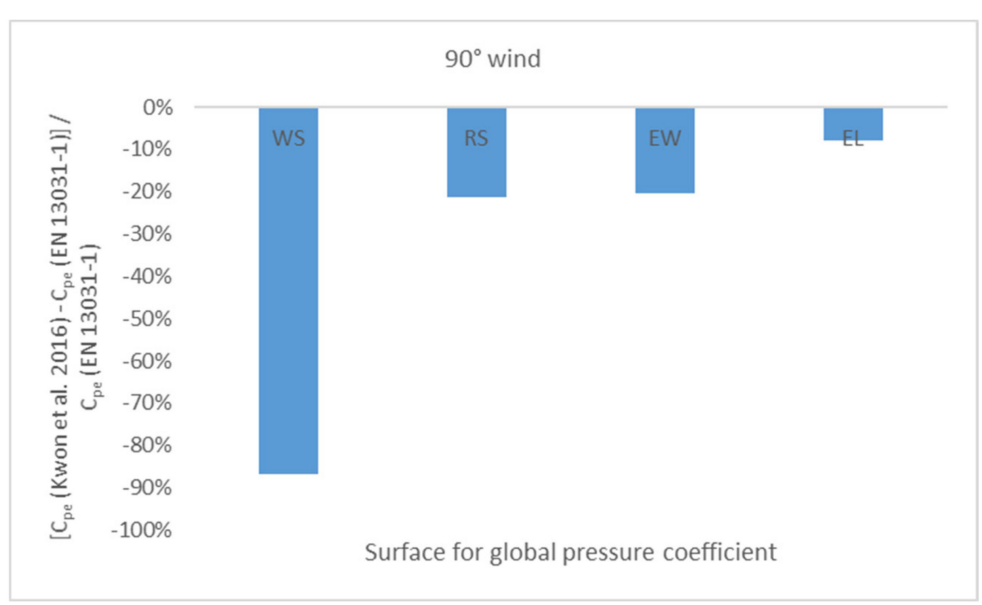

(b)

Figure 7. Difference in average external pressure coefficients for wall and roof surfaces as provided by Kwon et al. [7] and EN 13031-1 European Standard for single-span arched roof greenhouses, considering: (a) $0^{\circ}$-wind; and (b) $90^{\circ}$-wind. 


\section{Comparison Between EN 13031-1-Provided and Measured Wind Pressures for Multi-Span Greenhouses}

Section 5 focuses on single-span greenhouse structures. Going a step forward, this section focuses on multi-span greenhouses. Bronkhorst et al. [18] performed a review of published experimental studies that provide pressure coefficients on multi-span duo-pitch greenhouses and compared these coefficients with the EN 1991-1-4 and EN 13031-1 provisions. Table 8 summarizes the corresponding review results for four multi-span greenhouses with more than five spans each, and wind loading perpendicular to the ridge. As can be seen, although EN 1991-1-4 is not always conservative, in the sense of giving pressure coefficients lower than the measured ones, EN 13031-1 is practically always conservative, in the sense of giving pressure coefficients higher than or equal to the measured ones.

Given that all the experimental studies mentioned above on multi-span greenhouses considered up to nine spans, Bronkhorst et al. [18] performed wind tunnel tests on multi-span duo-pitch greenhouses having up to ninety spans, to determine the horizontal wind loads and compare them with the European standards.

The experiments took place in the open-circuit atmospheric boundary layer wind tunnel of TNO in the Netherlands, with the test section having a width of $3 \mathrm{~m}$ and height of $2 \mathrm{~m}$. Further details on the experimental procedure can be found in the original paper. Static force measurements were performed in nine models, while surface pressure measurements were carried out on one (slightly different in terms of geometry) 30-span model, considering various wind directions. All models had the same geometric scale, that is $1 / 250$. Specifically, in full-scale terms:

- The nine greenhouses had a ridge height of $8.1 \mathrm{~m}$, an eaves height of $7.0 \mathrm{~m}$, and a roof height of $1.1 \mathrm{~m}$. The roof span was $5.0 \mathrm{~m}$ and the roof angle of $24.3^{\circ}$. The width was varied from 50 (10 spans) to $450 \mathrm{~m}$ (90 spans).

- The 30-span greenhouse had a ridge height of $7.5 \mathrm{~m}$, an eaves height of $6.4 \mathrm{~m}$, and a roof height of $1.1 \mathrm{~m}$. The span was $5.0 \mathrm{~m}$ and the roof pitch angle of $23.3^{\circ}$.

Clearly, the geometric scale of the models (1/250) poses a question on the representativeness of the measured pressures for actual structures and, as a result, on the reliability of the comparisons with the standard provisions. It is worth noting, solely for comparative reasons, that the geometric scale in the experiments of Kwon et al. (2016) [7], described in the previous section, was 1/20, while the scales in Moriyama et al. [16] and Yang et al. [17] were 1/20 and 1/6, respectively (see Section 4.1). This indicates that the geometric scale of Bronkhorst et al. [18] models is more than an order of magnitude smaller compared with other similar studies.

The authors computed both mean and peak load coefficients (forces and pressures) and compared the results with the European standard provisions. Table 9 summarizes the mean and peak coefficients for the 30-span multi-span greenhouse tested and shows that EN 13031-1 gives practically always higher values for pressure coefficients.

However, when considering horizontal force coefficients (see Table 9), EN 13031-1 gives lower values than both mean and peak measured ones for Spans 10-30. For Spans 2-9, measurements agree with EN 13031-1 and, for Span 1 EN 13031-1 predicts remarkably higher values.

Finally, when considering the models tested in their entirety, Bronkhorst et al. [18] concluded that EN 13031-1 provides conservative estimates for duo-pitch greenhouses smaller than 20 spans (i.e., $100 \mathrm{~m}$ ), and non-conservative estimates for duo-pitch greenhouses larger than 20 spans (i.e., $100 \mathrm{~m}$ ). Particularly, at 90 spans (i.e., $450 \mathrm{~m}$ ), the overall horizontal wind force was found to be two-times greater. It should be noted that the work of Bronkhorst et al. also presents several interesting issues related to European standards, which, however, are not covered here. 
Table 8. Area-averaged pressure coefficients from full-scale measurements and external pressure coefficients representative for an area of $10 \mathrm{~m}^{2}$ from EN13031- 1 and EN1991-1-4 for four multi-span duo-pitch greenhouses with wind perpendicular to the ridge, after [18].

\begin{tabular}{|c|c|c|c|c|c|c|c|c|c|c|c|c|c|c|c|}
\hline $\mathrm{n}_{\mathrm{s}}$ & $\mathrm{s}(\mathrm{m})$ & $1(\mathrm{~m})$ & $\mathrm{h}_{\mathrm{e}}(\mathrm{m})$ & $\mathrm{H}(\mathrm{m})$ & $\alpha\left(^{\circ}\right)$ & ReferenceFront & Span 1 & Span 2 & Span 3 & Span 4 & Span 5 & Span 6 & Span 7 & Span 8 & Rear \\
\hline \multirow{3}{*}{7} & \multirow{3}{*}{3.2} & \multirow{3}{*}{63.0} & \multirow{3}{*}{2.35} & \multirow{3}{*}{3.1} & \multirow{3}{*}{26} & 0.52 & $\begin{array}{l}-0.76 / \\
-0.94\end{array}$ & $\begin{array}{l}-0.7 / \\
-0.45\end{array}$ & $\begin{array}{l}-0.29 / \\
-0.4\end{array}$ & - & - & - & - & - & - \\
\hline & & & & & & EN13031-1 0.6 & $\begin{array}{l}-0.84 \& \\
0.3 /-1\end{array}$ & $-0.7 /-0.5$ & $-0.4 /-0.5$ & $-0.4 /-0.5$ & $-0.4 /-0.5$ & $-0.4 /-0.5$ & $-0.4 /-0.5$ & - & -0.3 \\
\hline & & & & & & EN1991-1-40.7 & $\begin{array}{c}-0.36 \& \\
0.43 / \\
-0.83\end{array}$ & $\begin{array}{l}-0.57 / \\
-0.5\end{array}$ & $\begin{array}{l}-0.34 / \\
-0.5\end{array}$ & $\begin{array}{l}-0.34 / \\
-0.5\end{array}$ & $\begin{array}{l}-0.34 / \\
-0.5\end{array}$ & $\begin{array}{l}-0.34 / \\
-0.5\end{array}$ & $\begin{array}{l}-0.34 / \\
-0.5\end{array}$ & - & -0.3 \\
\hline \multirow{3}{*}{6} & \multirow{3}{*}{6.6} & \multirow{3}{*}{79.6} & \multirow{3}{*}{2.4} & \multirow{3}{*}{4.0} & \multirow{3}{*}{26} & 0.66 & $\begin{array}{l}-0.11 / \\
-1.23\end{array}$ & $\begin{array}{l}-1.12 / \\
-0.66\end{array}$ & $\begin{array}{l}-0.45 / \\
-0.53\end{array}$ & $\begin{array}{l}-0.22 / \\
-0.52\end{array}$ & - & $\begin{array}{l}-0.43 / \\
-0.56\end{array}$ & - & - & -0.44 \\
\hline & & & & & & EN13031-1 0.6 & $\begin{array}{c}0 \& 0.3 \\
/-0.8\end{array}$ & $\begin{array}{l}-0.62 / \\
-0.5\end{array}$ & $-0.4 /-0.5$ & $-0.4 /-0.5$ & $-0.4 /-0.5$ & $-0.4 /-0.4$ & - & - & -0.3 \\
\hline & & & & & & EN1991-1-40.7 & $\begin{array}{c}-0.31 \& \\
0.4 /-0.83\end{array}$ & $\begin{array}{c}-0.57 / \\
-0.5\end{array}$ & $\begin{array}{l}-0.34 / \\
-0.5\end{array}$ & $\begin{array}{l}-0.34 / \\
-0.5\end{array}$ & $\begin{array}{l}-0.34 / \\
-0.5\end{array}$ & $\begin{array}{l}-0.34 / \\
-0.5\end{array}$ & - & - & -0.3 \\
\hline \multirow{3}{*}{8} & \multirow{3}{*}{6.4} & \multirow{3}{*}{88.0} & \multirow{3}{*}{2.8} & \multirow{3}{*}{3.9} & \multirow{3}{*}{20} & 0.32 & $\begin{array}{l}-0.85 / \\
-1.01\end{array}$ & $\begin{array}{l}-0.77 / \\
-0.56\end{array}$ & $\begin{array}{l}-0.4 / \\
-0.55\end{array}$ & - & - & - & - & $\begin{array}{l}-0.31 / \\
-0.47\end{array}$ & -0.32 \\
\hline & & & & & & EN13031-1 0.6 & $\begin{array}{l}-0.82 \& \\
0.3 /-1\end{array}$ & $-0.7 /-0.5$ & $-0.4 /-0.5$ & $-0.4 /-0.5$ & $-0.4 /-0.5$ & $-0.4 /-0.5$ & $-0.4 /-0.4$ & $-0.4 /-0.4$ & -0.3 \\
\hline & & & & & & EN1991-1-40.7 & $\begin{array}{c}-0.37 \& \\
0.29 / \\
-0.87\end{array}$ & $\begin{array}{l}-0.53 / \\
-0.52\end{array}$ & $\begin{array}{l}-0.32 / \\
-0.52\end{array}$ & $\begin{array}{l}-0.32 / \\
-0.52\end{array}$ & $\begin{array}{l}-0.32 / \\
-0.52\end{array}$ & $\begin{array}{l}-0.32 / \\
-0.52\end{array}$ & $\begin{array}{l}-0.32 / \\
-0.52\end{array}$ & $\begin{array}{l}-0.32 / \\
-0.52\end{array}$ & -0.3 \\
\hline \multirow{3}{*}{52} & \multirow{3}{*}{3.2} & \multirow{3}{*}{111.0} & \multirow{3}{*}{3.0} & \multirow{3}{*}{3.75} & \multirow{3}{*}{24} & 0.32 & $\begin{array}{l}-0.93 / \\
-1.02\end{array}$ & $\begin{array}{l}-0.84 / \\
-0.71\end{array}$ & $\begin{array}{l}-0.49 / \\
-0.56\end{array}$ & $\begin{array}{l}-0.4 / \\
-0.51\end{array}$ & $\begin{array}{l}-0.36 / \\
-0.48\end{array}$ & $\begin{array}{l}-0.32 / \\
-0.43\end{array}$ & $\begin{array}{l}-0.31 / \\
-0.44\end{array}$ & - & - \\
\hline & & & & & & EN13031-1 0.6 & $\begin{array}{l}-1.03 \& \\
0.3 /-1\end{array}$ & $-0.7 /-0.5$ & $-0.4 /-0.5$ & $-0.4 /-0.5$ & $-0.4 /-0.5$ & $-0.4 /-0.5$ & $-0.4 /-0.5$ & $-0.4 /-0.5$ & -0.3 \\
\hline & & & & & & EN1991-1-40.7 & $\begin{array}{c}-0.42 \& \\
0.4 /-0.84\end{array}$ & $\begin{array}{l}-0.56 / \\
-0.5\end{array}$ & $\begin{array}{l}-0.34 / \\
-0.5\end{array}$ & $\begin{array}{l}-0.34 / \\
-0.5\end{array}$ & $\begin{array}{l}-0.34 / \\
-0.5\end{array}$ & $\begin{array}{l}-0.34 / \\
-0.5\end{array}$ & $\begin{array}{l}-0.34 / \\
-0.5\end{array}$ & $\begin{array}{l}-0.34 / \\
-0.5\end{array}$ & -0.3 \\
\hline
\end{tabular}


Table 9. Pressure coefficients for the 30-span multi-span greenhouse (the values for Spans 3-9 and 10-30 are average values over all roof spans). cp, pressure coefficient; $\mathrm{c}_{\mathrm{pe}, 10}$, external pressure coefficient representative for an area of $10 \mathrm{~m}^{2} ; \mathrm{c}_{\mathrm{Fx}, \mathrm{rs}}$, horizontal peak force coefficient per roof span without lack of correlation; $\mathrm{c}_{\mathrm{Fx}, \mathrm{rs}}$, 10, code calibrated overall force coefficient; $\mathrm{c}_{\mathrm{f}, \mathrm{rs}}$, horizontal force coefficient per roof span, after [18].

\begin{tabular}{|c|c|c|c|c|c|c|c|c|c|c|c|}
\hline & & \multirow{2}{*}{ Front } & \multicolumn{2}{|c|}{ Span 1} & \multicolumn{2}{|c|}{ Span 2} & \multicolumn{2}{|c|}{ Span 3} & \multicolumn{2}{|c|}{ Spans 10-30 } & \multirow{2}{*}{ Rear } \\
\hline & & & $\begin{array}{l}\text { Wind } \\
\text { Facing }\end{array}$ & Lee Facing & $\begin{array}{l}\text { Wind } \\
\text { Facing }\end{array}$ & Lee Facing & $\begin{array}{l}\text { Wind } \\
\text { Facing }\end{array}$ & Lee Facing & $\begin{array}{l}\text { Wind } \\
\text { Facing }\end{array}$ & Lee Facing & \\
\hline \multicolumn{12}{|l|}{ Pressure coefficients } \\
\hline Pressure measurements [18] & $c_{p}$ & 0.50 & -0.43 & -0.70 & -0.60 & -0.30 & -0.05 & -0.18 & 0.00 & -0.14 & -0.15 \\
\hline [18] & $\mathrm{c}_{\mathrm{pe}, 10}$ & 0.67 & -0.580 .05 & -0.73 & -0.720 .06 & -0.36 & -0.180 .20 & -0.23 & -0.130 .21 & -0.20 & -0.19 \\
\hline EN13031-1 & $c_{\mathrm{pe}, 10}$ & 0.60 & -1.060 .30 & -1.00 & -0.70 & -0.50 & -0.40 & -0.50 & -0.40 & -0.40 & -0.30 \\
\hline EN1991-1-4 & $\mathcal{C}_{\mathrm{pe}, 10}$ & 0.70 & -0.460 .42 & -0.84 & -0.56 & -0.51 & -0.33 & -0.51 & -0.33 & -0.51 & -0.30 \\
\hline \multicolumn{12}{|l|}{ Roof span force coefficients } \\
\hline $\begin{array}{l}\text { Static force measurements } \\
\text { [18] }\end{array}$ & $\mathrm{c}_{\mathrm{Fx}, \mathrm{rs}}$ & - & - & & - & & - & & 0.07 & & - \\
\hline Pressure measurements [18] & $c_{\mathrm{Fx}, \mathrm{rs}}$ & - & 0.27 & & -0.30 & & 0.09 & & 0.09 & & - \\
\hline [18] & $\mathrm{c}_{\mathrm{Fx}, \mathrm{rs}, 10}$ & - & 0.78 & & 0.42 & & 0.30 & & 0.29 & & - \\
\hline EN13031-1 & $c_{f, r s}$ & - & 1.30 & & -0.20 & & 0.10 & & 0.00 & & - \\
\hline EN1991-1-4 & $c_{\text {frrs }}$ & - & 1.26 & & -0.05 & & 0.17 & & 0.17 & & - \\
\hline
\end{tabular}




\section{Conclusions}

Among the loads acting on greenhouses, wind loads are the major ones (together with snow loads, which, however, are not considered in the present study). Therefore, design and construction of greenhouses should take into consideration wind loads in order to ensure seamless operation, overall stability and durability, and safety. Classification and design of greenhouses is typically based on European standards, but some recent research studies $[7,13,14,18]$ suggest that greenhouse design standards should be revised in order to ensure structural safety of greenhouses subject to strong wind loads. Triggered by these outcomes, this paper evaluates the existing literature on the topic, including a summary of the state-of-the-art computational and experimental methods for determining wind pressure coefficients.

Then, given the absence of comparisons with Standards in $[7,13,14]$, the present paper compares the global pressure coefficients provided by Kwon et al. [7] based on wind tunnel measurements with those suggested by the EN 13031-1 Standard. It is shown for both pitched and arched single-span greenhouses that:

- For a $0^{\circ}$-wind direction, the measured pressure coefficients for the wall and roof surfaces on the leeward side (WL and RL) are higher than those suggested in EN 13031-1. Contrary, EN 13031-1 coefficients for the roof surfaces on the windward side (RW) are higher than the measured ones. The pressure coefficients for the wall surfaces on the windward side (WW) and at the end parts (ES) are practically the same.

- For a $90^{\circ}$-wind direction, EN 13031-1 systematically leads to higher pressure coefficients than Kwon et al., particularly concerning the surfaces of the side walls (WS).

Therefore, according to the present comparative results, EN 13031-1 seems to not always be conservative in terms of magnitude of pressure coefficients for a $0^{\circ}$-wind direction. This conclusion cannot be considered as generally valid, however, given: (a) the scale of the tested models (1/20); and (b) the limited number of tests performed (six pitched and six arched single-span greenhouses). Moreover, it has to be noted for sake of completeness that standards include many more layers beyond pressure coefficients to guarantee structural safety (including several layers of safety factors).

A similar conclusion but for multi-span greenhouses was derived by Bronkhorst et al. [18]: "EN 13031-1 provides non-conservative outcomes for the overall horizontal wind force on the investigated duo-pitch greenhouse type with more than 20 spans. On the other hand, EN 1991-1-4 is increasingly conservative with larger number of spans". However, this conclusion is questionable too given: (a) the scale of the tested models (1/250); and (b) the limited number of tests performed (13 in total).

In summary, more experimental and numerical studies are necessary to evaluate the conclusion of these recent studies on the sufficiency and revision of standards due to: (a) the limited amount of recent data that support this outcome (presented only by two research groups $[7,13,14,18]$, and considering here, as directly comparable with EN 13031-1, 25 tests in total, with only few of them supporting this outcome); (b) the scale of the models in these studies (1/20 and 1/250, respectively); (c) the certain cases where EN 13031-1 gives lower pressure coefficients is not a systematic outcome and appears in the extreme cases of single-span greenhouses and long multi-span greenhouses with more than 20 spans, e.g. $100 \mathrm{~m}$ in [18]; (d) the assumptions behind the coefficients provided in recent papers (e.g., accuracy of pressure measurements in tests and consideration only of mean values, not peak, in CFD computations by Kim et al.); (e) the complexity of the problem under investigation; and (f) the fact that EN 13031-1 was recently revised.

Funding: This research received no external funding.

Conflicts of Interest: The authors declare no conflict of interest. 


\section{References}

1. Research and Markets. Commercial Greenhouse Market by Equipment (Heating Systems, Cooling Systems, and Others), Type (Glass Greenhouse, Plastic Greenhouse and Others), Crop Type, \& by Region-Global Trends \& Forecasts to 2020. Available online: http://www.researchandmarkets.com/research/whwdg8/ commercial (accessed on 25 February 2020).

2. Westland (Municipality), Netherlands. Wikipedia, the Free Encyclopedia. Available online: https://en. wikipedia.org/wiki/Westland_(municipality),_Netherlands (accessed on 25 February 2020).

3. CEN. EN 13031-1: Greenhouses: Design and Construction-Part 1: Commercial Production Greenhouses; European Committee for Standardization: Brussels, Belgium, 2019.

4. Cook, N.J. The Designer's Guide to Wind Loading of Building Structures_Part 1: Background, Damage Survey, Wind Data and Structural Classification; Butterworths: London, UK, 1985; p. 371.

5. Cook, N.J. The Designer's Guide to Wind Loading of Building Structures—Part 2: Static Structures; Butterworths: London, UK, 1990; p. 586.

6. CEN. Eurocode EN 1991-1-4: Actions on Structures-Part 1-4: General Actions-Wind Actions; European Committee for Standardization: Brussels, Belgium, 2010.

7. Kwon, K.; Kim, D.; Kim, R.; Ha, T.; Lee, I. Evaluation of wind pressure coefficients of single-span greenhouses built on reclaimed coastal land using a large-sized wind tunnel. Biosyst. Eng. 2016, 141, 58-81. [CrossRef]

8. Gavanski, E.; Cook, N.J. Evaluation of XIMIS for Assessing Extreme Pressure Coefficients. Front. Built Environ. 2019, 5, 1-15. [CrossRef]

9. Fouad, N.S.; Mahmoud, G.H.; Nasr, N.E. Comparative study of international codes wind loads and CFD results for low rise buildings. Alex. Eng. J. 2008, 57, 3623-3639. [CrossRef]

10. Gomes, M.G.; Rodrigues, A.M.; Mendes, P. Experimental and numerical study of wind pressures on irregular-plan shapes. J. Wind Eng. Ind. Aerodyn. 2005, 93, 741-756. [CrossRef]

11. Hwang, H.S.; Lee, I.B. Wind pressure coefficient determination for greenhouses built in a reclaimed land using CFD technique. In Proceedings of the International Conference of Agricultural Engineering (AgEng 2014), Lausanne, Switzerland, 6-10 July 2014; pp. 1-8.

12. Kuroyanagi, T. Investigating air leakage and wind pressure coefficients of single-span plastic greenhouses using computational fluid dynamics. Biosyst. Eng. 2017, 163, 15-27. [CrossRef]

13. Kim, R.; Lee, I.; Kwon, K. Evaluation of wind pressure acting on multi-span greenhouses using CFD technique, Part 1: Development of the CFD model. Biosyst. Eng. 2017, 164, 235-256. [CrossRef]

14. Kim, R.; Hong, S.; Lee, I.; Kwon, K. Evaluation of wind pressure acting on multi-span greenhouses using CFD technique, Part 2: Application of the CFD model. Biosyst. Eng. 2017, 164, 257-280. [CrossRef]

15. Shklyar, A.; Arbel, A. Numerical model of the three-dimensional isothermal flow patterns and mass fluxes in a pitched-roof greenhouse. J. Wind Eng. Ind. Aerodyn. 2004, 92, 1039-1059. [CrossRef]

16. Moriyama, H.; Sase, S.; Uematsu, Y.; Yamaguchi, T. Wind pressure coefficient of a pipe-framed greenhouse and influence if the side gable openings using a wind tunnel. J. SASJ 2008, 38, 237-248.

17. Yang, Z.Q.; Li, Y.X.; Xue, X.P.; Huang, C.R. Wind loads on single-span plastic greenhouses and solar greenhouses. HortTechnology 2013, 23, 622-628. [CrossRef]

18. Bronkhorst, A.J.; Geurts, C.P.; Van Bentum, C.A.; Van der Knaap, L.P.M.; Pertermann, I. Wind Loads for Stability Design of Large Multi-Span Duo-Pitch Greenhouses. Front. Built Environ. 2017, 3, 1-21. [CrossRef]

19. Mathews, E.H.; Meyer, J.P. Numerical modelling of wind loading on a film clad greenhouse. Build. Environ. 1987, 22, 129-134. [CrossRef]

20. Hoxey, R.P.; Wells, D.A. Full-scale wind pressure measurements on a twin-span $12.2 \times 12.2 \mathrm{~m}$ inflated roof greenhouse. J. Wind Eng. Ind. Aerodyn. 1977, 2, 211-221. [CrossRef]

21. Wells, D.A.; Hoxey, R.P. Measurements of wind loads on full-scale glasshouses. J. Wind Eng. Ind. Aerodyn. 1980, 6, 139-167. [CrossRef]

22. Hoxey, R.P.; Richardson, G.M. Wind loads on film plastic greenhouses. J. Wind Eng. Ind. Aerodyn. 1983, 11, $225-237$. [CrossRef]

23. Hoxey, R.P.; Richardson, G.M. Measurements of wind loads on full-scale film plastic clad greenhouses. J. Wind Eng. Ind. Aerodyn. 1984, 16, 57-83. [CrossRef] 
24. Richardson, G.M.; Westgate, G.R. Full-scale measurements of the wind loads on film plastic clad greenhouses: A comparison of measured and calculated strains on the supporting hoops of a tunnel greenhouse. J. Agric. Eng. Res. 1986, 33, 101-110. [CrossRef]

25. Richardson, G.M. Wind loads on a full-scale film-plastic clad greenhouse: With and without shelter from a windbreak. J. Wind Eng. Ind. Aerodyn. 1986, 23, 321-331. [CrossRef]

26. Hoxey, R.P.; Moran, P. Full Scale Wind Pressure and Load Experiments-Multispan $167 \times 111$ m Glasshouse (Venlo); Divisional Note, AFRC Institute of Engineering Research: Silsoe, UK, 1991.

C 2020 by the author. Licensee MDPI, Basel, Switzerland. This article is an open access article distributed under the terms and conditions of the Creative Commons Attribution (CC BY) license (http://creativecommons.org/licenses/by/4.0/). 